This is a self-archived version of an original article. This version may differ from the original in pagination and typographic details.

Author(s): Kaukua, Jari

Title: The Question of Providence and the Problem of Evil in Suhrawardī

Year: 2021

Version: Accepted version (Final draft)

Copyright: @ Koninklijke Brill NV, Leiden, 2021

Rights: In Copyright

Rights url: http://rightsstatements.org/page/lnC/1.0/?language=en

Please cite the original version:

Kaukua, J. (2021). The Question of Providence and the Problem of Evil in Suhrawardī. Oriens :

Journal of Philosophy, Theology and Science in Islamic Societies, 49(3-4), 244-268.

https://doi.org/10.1163/18778372-12340008 


\title{
The Question of Providence and the Problem of Evil in Suhrawardī
}

\begin{abstract}
Šihāb al-Dīn al-Suhrawardī's philosophical works seem to contain two conflicting views on providence: in the Talwịhăt and the Mašări, he endorses the Avicennian view, only to deny providence altogether in the Hikmat al-išrāq. This contribution aims to explain the seeming inconsistency by investigating it in light of the underlying question of God's knowledge of particular things. I will also argue that despite his qualms concerning providence, Suhrawardī accepts the closely related Avicennian answer to the problem of evil.
\end{abstract}

\section{Keywords}

Šihāb al-Dīn al-Suhrawardī - Abū l-Barakāt al-Baġdādī - providence - problem of evil - God's knowledge of particulars

The background for sixth/twelfth-century approaches to the question of providence ('ināya) and the intimately connected problem of evil in Islamic philosophy was provided by Avicenna's emanationist model. Key features of this model are its strong determinism and, from the point of view of orthodox Ash'arite theology, God's detached relation to the world. He is an benevolent and omniscient creator of the world, who has fashioned the world according to the best possible order, and a correct understanding of the world will reveal providence at work. However, the providential order is designed to produce the greatest possible amount of good on the level of the whole, which means that individual entities and their destinies are left to the mercy of fortuitous causal relations. To apply Avicenna's own example, a world without fire would lack a principle that is necessary for the existing and flourishing of life, and although fire may also cause undeserved harm by burning down a forest inhabited by an entire ecosystem of plants and animals, it would be a vastly greater evil to refrain from creating a great good for the sake of avoiding a lesser evil. Even in the best possible world, some individuals may have to draw the shortest straw and suffer a life of misery, but in Avicenna's book this counts as a sufficient answer to the problem of evil - the providential blueprint of the world is the best possible order, proper to a benevolent Creator:

Hence, it must be known that providence is the First's knowing, by His essence, what has existence in the order of the good, His being a cause, by His essence, for the good and the perfect in accordance with possibility, and His being satisfied with it in the aforementioned manner, so that He understands the order of the good in the most profound way possible. Hence, what He understands as an order and good emanates from Him in the most profound way, which He understands as an emanation [that is] the most complete possible execution of the order, and this is the meaning of providence. ${ }^{1}$

\footnotetext{
${ }^{1}$ Avicenna, Šifä’: Ilāhīyāt (=Avicenna, The Metaphysics of The Healing. Al-Shifä’: al-Ilāhiyyāt. A Parallel English-Arabic Text, ed./tr. by M. E. Marmura (Provo: Brigham Young University Press), book IX, chapter 6.1, 339. For studies of Avicenna's theory of providence, see Marwan Rashed, 'Théodicée et approximation: Avicenne', Arabic Sciences and
} 
Šihāb al-Dīn al-Suhrawardī (d. 587/1191), the founder of the so-called illuminationist (išrāqì) school of philosophy, seems to endorse the Avicennian model with few, if any, emendations in some of his central works, such as the Talwịhăt al-lawhiya wa-I-aršilya and the Mašāri ' wa-l-muțārahăt. However, the founding work of the new išrāqi philosophy, the Hikmat al-išrāq, reveals him flatly denying God's providence of the world. This arouses the question of which of the alternatives, if either, was Suhrawardi's considered position, and more generally, what was Suhrawardì's relation to the Avicennian background of his thought. ${ }^{2}$ In this contribution, I begin by sketching out the seemingly Avicennian theory of providence in the Talwīhăt and the Mašăric wa-l-muțārahăăt, as a background for explaining the sense and motivation of the illuminationist denial of the theory. I will conclude by arguing that his qualms against providence notwithstanding, Suhrawardi endorsed the Avicennian solution to the problem of evil, and indeed elaborates on it at some length in an argument against theological pleas for God's interference on behalf of believers.

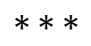

Although much of the Talwịhăt as well as the considerably more voluminous Mašăric waI-muțārahătcan be characterised as an exercise in Avicennian philosophy, these works do contain some doctrines that deviate from Avicenna, a particularly notable case being the theory of

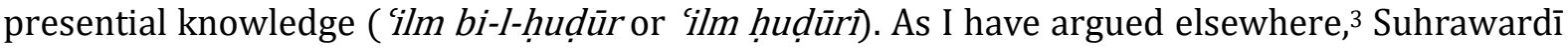
introduces the theory as a solution to the problem of God's knowledge of particulars. It is therefore not surprising that it reappears in Suhrawardī's discussion of providence. Having first stated the standard Avicennian argument for the atemporality of God's knowledge (if God's knowledge were temporal, or tensed, it would have to change in tense, from the future through the present to the past, as its object changes, which would violate God's immutability), Suhrawardī argues that God's knowledge can only be presential, for any other way of explaining His epistemic access to the creation would entail multiplicity in Him. This is because in the Avicennian model, intellection takes place when an intelligible form inheres in an intellect, which

Philosophy 10/2 (2000): 223-257; Carlos Steel, 'Avicenna and Thomas Aquinas on Evil', in Avicenna and His Heritage: Acts of the International Colloquium, Leuven-Louvain-la-Neuve September 8-September 11, 1999, ed. by Jules Janssens and Daniel de Smet (Leuven: Leuven University Press, 2002), 171-196; Catarina Belo, Chance and Determinism in Avicenna and Averroes, Islamic Philosophy, Theology and Science Texts and Studies 69 (Leiden and Boston: Brill, 2007), 109-119; Sari Nusseibeh, 'Avicenna: Providence and God's Knowledge of Particulars', in Avicenna and His Legacy: A Golden Age of Science and Philosophy, ed. by Y. T. Langermann (Turnhout: Brepols, 2009), 275-288; Jules Janssens, 'What about Providence in the Best of All Possible Worlds? Avicenna and Leibniz', in Fate, Providence and Moral Responsibility in Ancient, Medieval and Early Modern Thought: Studies in Honor of Carlos Steel, ed. by Pieter d'Hoine and Gerd van Riel, Ancient and Medieval Philosophy Series 1, 49 (Leuven: Leuven University Press, 2014), 441-454; Olga L. Lizzini, 'Matter and Nature: On the Foundations of Avicenna's Theory of Providence: an Overview', Intellectual History of the Islamicate World 7 (2019): 7-34; Jonathan Dubé, 'Hayy ibn Yaqzān's of the Two Generous Men in Avicenna's Decree and Determination (R. fi l-Qadā' wa-l-qadar)', Intellectual History of the Islamicate World 7 (2019): 35-60; and Ayman Shihadeh, 'Avicenna's Theodicy and al-Rāzī's Anti-Theodicy', Intellectual History of the Islamicate World 7 (2019): 61-84.

${ }^{2}$ A developmental account can, I think, be ruled out at the outset, because the Mašări ${ }^{c}$ was most likely completed after the Hikmat al-išrăq. For a concise argument for the dating as well as an interesting proposal of the relation between Suhrawardī's works, see John Walbridge, 'Suhrawardì's (d. 1191) Intimations of the Tablet and the Throne: The Relationship of Illuminationism and the Peripatetic Philosophy', in The Oxford Handbook of Islamic Philosophy, ed. by Khaled El-Rouayheb and Sabine Schmidtke (New York: Oxford University Press, 2017), 255-277.

3 Jari Kaukua, 'Suhrawardī's Knowledge as Presence in Context', Studia Orientalia 114 (2013): 309-324. 
entails the difference between a subject and its attribute, and thereby multiplicity. The concept of presential knowledge, by contrast, enables Suhrawardī to conceive of God's knowledge in purely relational terms. As a relation, the world's presence to God does not violate the absolute unity of the divine subject, for what is present to God need not be present in Him, and so the divine regard remains one despite the multiplicity of things in its spotlight. By the same token, change in one of two relata does not entail change in the other; again, the spotlight of God's regard stands immutable despite the constant flux of things to and from it. ${ }^{4}$

In fact, however, God's cognitive relation to the world is not quite as straightforward, for the world is present to God as a hierarchy of mediated relations. Here Suhrawardī returns to standard Avicennian emanation theory: immediately present to God is only the first intellect that is emanated from Him, and through it the other intellects, and only through further mediations the rest of the created universe. Yet at the same time he makes another interesting deviation from Avicenna, albeit tacitly at this stage, for he states that the content of the Avicennian God's unchanging intellection, that is, the providential order of the world, first emerges at the level of the emanated intellects:

This order (al-nizām) that exists in the world does not emerge randomly, and so there is a representation of its form in the high intellectual principles, for intellects are capable of conception and representation. The principles' knowledge of the quality of the order of all and of what there must be in it is providence (al-ināya), and in the case of the First it is not additional to His essence and His not being absent from Himself and His concomitants, [but] in the case of the intellects it can be an additional inscription (naqšan) caused by the separation from matter, the lack of any veil between them and their concomitants and principles, and the possibility of being inscribed (al-intiqās). The inscriptions of the intellects are also present to Him, elevated is He, and likewise the inscriptions of the souls of the spheres in relation to what is above them, for the presence of the inscription of all lowly things is related to what is above them, as you are familiar with from the presence of imaginal forms to the soul. ${ }^{5}$

The doctrine of presential knowledge notwithstanding, the picture yielded here seems essentially Avicennian at first sight. The metaphysical structure of the world is a harmonious order, which is inscribed in the celestial intellects and imitated by the celestial souls in their rotation of the celestial spheres. Just as in Avicenna, God knows this order, and in the sense that it is eternally known by the principles that bring other things into existence in accordance with it, it can be called providential. But Suhrawardī reminds the reader that as he has just explicated by means of the concept of presence, God does not know this order by having its form added to His essence; rather, the order inheres as an attribute in the celestial intellects. However, since God is aware of

\footnotetext{
4 Suhrawardī, Talwīhāat section III ('ilm ilāhì), mawrid 3, section 2, §56 (two editions: CEuvres philosophiques et mystiques (Shihābuddīn Yahyā Suhrawardī). Tome I: La Métaphysique: 1. Kitāb al-Talwīḥāt, 2. Kitāb al-muqāwamāt, 3. Kitābal-Mashāric wa-l-muțārahāt, ed. by Henry Corbin (Tehran: Institute d'Études et des Recherches Culturelles, 2009), 1-121; Sohravardī, Al-Talwīhāt al-Lawhiyyah wa-l- 'Aršiyyah, ed. by Nağaf-qulī Habībī (Tehran: Iranian Institute of Philosophy, 2009), 75-76 (Corbin), 244-245 (Ḥabībī); Suhrawardī, al-Mašāric wa-l-muțāraḥāt (in Šihāb al-Dīn Yahyā Suhrawardī, CEuvres philosophiques et mystiques, Tome I, ed. by Henry Corbin) section III ('ilm ilāhî), mashra' 7, faṣl 1.§210, 487-488.

5 Suhrawardī, TalwīhāàtIII.3.2.56, 75-76 (Corbin), 244-245 (Habībī); cf. Id., al-Mašāric wa'l-muțārahāātIII.7.1.210, 487.
} 
Himself (or not absent from Himself) as well as all of His concomitants, ${ }^{6}$ the order is present to God through the presence of the intellects, which are His concomitants. The intellects in turn emanate the structure to the celestial souls, and together with their activity, further downwards to the lowest regions of the universe. Because this entire process can be traced back to the intellects and the structure they are eternally thinking of, it is present to and therefore known by God through the mediation of those intellects.

In his discussion of God's knowledge in the Mašăric wa-I-muțārahăt, Suhrawardī remarks that the theory presented in the Hikmat al-išrāq is superior to the theory of presential knowledge. ${ }^{7}$ At first glance, however, the two theories are remarkably similar. Suhrawardi does replace the concept of presence with the concepts of light ( $n \bar{u} r)$ and appearance or manifestation (zuhür), but there is no obvious difference between these concepts - indeed, from Shams al-Dīn al-Šahrazūrī (d. after 687/1288) onwards, Suhrawardī's commentators felt comfortable to speak alternately of light, manifestation and "išrāqī presence". Slight complications are of course due to the explicitly un-Avicennian model of the hierarchy of intellects in the Hikmat al-išrāq, which replaces the straightforward vertical model of ten celestial intellects with a complex series of emanations and reflections of innumerably many celestial intellects, or lights, at the level of the Avicennian sphere of the fixed stars. In Suhrawardī, the whole of this series, of which he only presents a sketch, amounts to an exhaustive system that includes independently subsisting Platonic Forms, ${ }^{8}$ which does signal a major metaphysical departure from Avicenna's Aristotelianism. Notwithstanding that, however, it does not entail any principal change in God's relation to the world - it is perfectly possible to identify the providential structure of the world inscribed in the ten intellects of the Talwịhăt and the Mašăric wa-l-muțārahăàt as the system of Platonic forms described in the Hikmat al-išrā q.

It is therefore somewhat striking to read Suhrawardi state, towards the end of the same passage, that later on in the work he "shall refute what they call 'providence'". ' 'They' here are most likely the Avicennian philosophers, whose theory of emanation Suhrawardī is revising, ${ }^{10}$ but the promised refutation is not as easy to trace. Later on in the work, however, Suhrawardi extrapolates on his reasons for rejecting the idea of providence. This extrapolation is part of a convoluted series of three arguments against the Avicennian theory of God's knowledge:

The Peripatetics and their followers say: the knowledge of the Necessary Existent is not additional to Him, but rather His not being absent from His own essence, which is separate from matter. They say: the existence of things is from His knowledge of them. So they are said: [1] If He knows and then something follows from knowledge,

\footnotetext{
${ }^{6}$ The Avicennian concept of self-awareness is the foundation of Suhrawardī's concept of presential knowledge, for as a cognitive relation, presence presupposes a subject that is aware of itself (or not absent from itself). See Jari Kaukua, Self-Awareness in Islamic Philosophy: Avicenna and Beyond (Cambridge: Cambridge University Press, 2015), 125142; and Mateus Domingues Da Silva, 'La métaphysique des lumières de Suhrawardī et la question de la connaissance divine', Mélanges de I'Institut dominicain d'études orientales 34 (2019): 147-197.

${ }^{7}$ Suhrawardī, Al-Mašāric wa'l-muțārahāt III.7.1.208, 484.

${ }^{8}$ Suhrawardī, Hikmat al-išrāq (in Šihāb al-Dīn Yahyā Suhrawardī, CEuvres philosophiques et mystiques. Tome II: 1. Le Livre de la Théosophie Orientale, 2. Le Symbole de foi des Philosophes, 3. Le Récit de l'Exil Occidental. Textes édités avec prolégomènes en français, ed. by Henry Corbin (Paris-Tehran: Tehran: Institute d'Études et des Recherches Culturelles, 2009), 1-260), qism II, maqāla 2, fașl 8 §150-153, 138-144.

${ }^{9}$ Suhrawardī, Hikmat al-išrā $q$ II.2.8.153, 144.

10 This is confirmed by Šahrazūrī, Šarh Hikmat al-išrāq (in Commentary on the Philosophy of Illumination by Shams alDin Muhammad Shahrazuri, ed. by Husayn Żiyā'ī Turbatī (Tehran: Institute for Humanities and Cultural Studies, 2001)), ad II.2.8.150-156, 367.21-23.
} 
then knowledge is prior to things and to not being absent from things, and so not being absent from things comes after they have been realised (tahaqquqihā). [2] And just as what He causes is different from His essence, similarly knowledge of what $\mathrm{He}$ causes is different from knowledge of His essence. [3] When it comes to saying that "His knowledge of His concomitant is included in His knowledge of His own essence", it is a futile statement, for knowledge is negative according to [the Peripatetic], and how can knowledge of things be classified under negation? Separation from matter is negative, as is not being absent, and not being absent cannot mean presence, because nothing is present to itself, for what is present is different from that to which there is presence, and so [presence] is only said of two things, whereas [not being absent] is more general. Hence, how can knowledge of another be classified under negation? [2] Moreover, risibility is something different from humanity, and so knowledge of it is different from knowledge of humanity. In our view, knowledge of risibility is not included in knowledge of humanity, for [humanity] does not refer to [risibility] by way of correspondence or implication (tadammunan) but by way of external reference. Hence, when we know risibility, we need another form, and without that form it is [only] potentially known to us. As regards the simile that they introduced in order to distinguish between differentiated knowledge of questions, potential knowledge of them, and questions in the case of which man finds in himself knowledge of their answers as soon as they are posed, it is of no use.11 For what man finds in himself when the questions are posed is potential knowledge, which he finds in himself as a disposition (malaka) and a capacity ( qudra) to answer these questions that have been posed. This potency is more proximate than it was before the question, for there are degrees to potency, and he does not know the answer of every single [question] in particular, unless he has the form of each one singly. The Necessary Existent is deemed above these things. [3] Besides, if ' $A$ ' is different from ' $B$ ', how can a negation be both knowledge of the two and providence of how they must be according to the order (al-nizām)? [1] If His knowledge of things occurs from the things, then prior providence of things and prior knowledge are refuted. ${ }^{12}$

Crucial for our concerns, Suhrawardī concludes the series of arguments on a somewhat elliptic denial of providence. However, the flat denial can be fleshed out into a proper piece of reasoning if we connect it to the first argument of the series. According to argument [1], if knowledge is not being absent from the object of knowledge, then it is founded on something from which the subject can be not absent and which therefore can be not absent from the subject. Hence, conceived in these terms, knowledge requires the positive existence of its object, in one way or another. While there might be nothing obviously wrong about this as far as everyday human knowledge is concerned, the case is different when we turn to God's providence: if worldly things must be there in order to be known, how can there be providence, or foreknowledge, of them?

Two things are particularly noteworthy about this passage. First of all, notice that Suhrawardī here attributes the concepts of presence and not being absent to the Avicennian

\footnotetext{
11 The source of this distinction is Avicenna, Šifä': Nafs (in Avicenna's De anima (Arabic Text). Being the Psychological Part of Kitāb al-shifä', ed. by Fazlur Rahman (London: Oxford University Press, 1959)), V.6, 242-243.

12 Suhrawardī, Hikmat al-išrāq II.2.10.161, 150-152. I have numbered the arguments for ease of reference. As far as I can see, there are only three arguments, the later ones being either mere variations or counterarguments to further defences of the Avicennian position.
} 
framework that he expressly renounces here. Although they seemed to represent Suhrawardi's own considered view in the Talwịhăt and the Mašăric wa-l-muțārahăt, we are here enlightened about their actual relation to the alternative illuminationist system: presence and not being absent are the best means available to a Peripatetic for making sense of God's knowledge of particulars, because the problem of negativity notwithstanding, they are at least free from the entailment of multiplicity in God that besets the alternative theory of intellectual forms inhering in God. Secondly, and as a consequence, Suhrawardī denies the Avicennian concept of providence as incoherentin the very terms of his expanded Peripateticism: it is the notion of not being absent that entails the incoherence. Moreover, since in Suhrawardī's time 'ināya was part and parcel of the Peripatetic theory of God's knowledge, this incoherence suffices to rule out the entire notion of God's foreknowledge.

After the critique, Suhrawardī's illuminationist alternative to the Peripatetic theory is spelled out in the immediately following passage:

Hence, the truth concerning knowledge is the principle of illumination ( $q \bar{a}$ cidatu ališrāq), that is, that His knowledge of Himself is His being a light to Himself and manifest to Himself, and His knowledge of things is their being manifest to Him either by themselves or through [the things] they depend on (muta'allaqãtihā), which are subject to the constant awareness of the high governors (al-mudabbirät). That is a relation whereas the absence of a veil is negative. What shows that this much is sufficient is that seeing is nothing but the relation of manifestation of something to the seer when there is no veil. His relation to all that is manifest to Him is seeing and perceiving it, and no number of intellectual relations necessitates multiplicity in His essence. As regards providence, there is no need for it. As regards the order (alnizām), it is concomitant to the marvelous arrangement and the relations concomitant to the separate [things] and their reflected radiations, as [explained] before. This providence is what they used to refute the principles of those, who subscribe to the luminous realities that have talismans, but it is itself invalid. Once it has been refuted, the arrangement of barriers (al-barāzih̆) ought to be due to the arrangement of pure lights and their illuminations, which are included in the causal descent that is impossible for barriers. ${ }^{13}$

Suhrawardi first states that conceiving of God's being and knowledge as light or manifestation liberates us from the negations in the Peripatetic concept of separation from matter or the presential concept of not being absent. In a sense, this is little more than a terminological move, since the theoretical functions of 'light' or 'manifestation' are very similar to those of 'presence' and 'not being absent', all notions attempting to explain God's knowledge of the world in relational terms. On the other hand, the point of the illuminationist concepts is to highlight the positive nature of cognitive existence, and to argue that we should take it as a metaphysically primitive fact, instead of attempting, like the Peripatetics, to explain cognition by means of more basic, albeit negative concepts. As such a primitive fact, cognition (conceived as light and manifestation) can then provide the foundation for a new metaphysical approach, which is precisely what happens in the second part of the Hikmat al-išrāq. Importantly for the present

13 Suhrawardī, Hikmat al-išrā $q$ II.2.10.162, 152-153. 
concern, however, the concept of light or manifestation retains all the explanatory virtues of the concepts of presence and not being absent; in particular, it enables Suhrawardì to still conceive of God's knowledge of the world in exclusively relational terms - as he says in the quote, when some of the gaps are filled, "[the created things'] being light and manifest to God is [also] a relation, [just like their presence or not being absent from Him,] whereas the absence of a veil[, unlike light or manifestation, has the downside of being a] negative [notion]".14

Moreover, the new concept of light or manifestation can dispense with the problematic idea of providence. The end of the dense passage also indicates that Suhrawardi's denial of providence is intimately linked to his endorsement of the theory of Platonic Forms. There is no room for providence, because the harmonious order of the world that was supposed to be the object of God's foreknowledge is actually a concomitant of, and therefore metaphysically posterior to, the system of celestial intellects that Suhrawardi identifies with the Platonic Forms. Here we have to bear in mind the first argument against the Peripatetics: if God's knowledge of the world is relational, the order must already be there in order for Him to know it, and so it cannot be due, and thereby subsequent, to His knowledge. Šahrazūrī, the first commentator on the Hikmat al-išrāq , spells out this connection by saying that if the providential order were inscribed in the celestial intellects, as explained in the Talwịhăt and the Mašăric wa-l-muțārahăàt, the multiplicity inherent in the order would have to be caused by something that is metaphysically prior to the intellects, simply because in an emanationist framework, all causation of existence is top-down. This has the awkward consequence that the order must, after all, be an object of God's thinking, which entails a distinction between a subject and object, as well as the inherent multiplicity of the order, and brings back the problem of God's unity that we started with. ${ }^{15}$

But this is not all, for a further contradiction between the idea of providence and the theory of Forms is due to the fact that providence undermines the causal role of the Forms. In order to see this, we have to unpack the loaded technical phrase "the luminous realities that have talismans", which refers to the Forms (the luminous realities) together with their immediate causal relations to their individual instantiations (the talismans). ${ }^{16}$ In speaking of the Forms together with their instantiations, Suhrawardi emphasises the inseparability of the Forms from their activity: the Forms are Forms precisely insofar as they are the causal principles to which the instantiations are traced back - the being of a light is its illumination. ${ }^{17}$ The problem with providence is that, again, it places the order metaphysically prior to what is ordered. Suhrawardī's contrary claim is that the order is concomitant to the Forms and that there is no order that could be taken apart from the constant downward causation through which the ceaselessly changing material world (the world of "barriers") imitates the arrangement of the Forms.

This has an important consequence for the question of the compass of God's knowledge. Proceeding in the order of emanation, if we consider the immediate object of God's knowledge, the difference between the illuminationist and the Peripatetic models does not seem that great

\footnotetext{
14 In this quote, I take "absence of a veil" to denote separation from matter, which in standard Peripatetic doctrine is the only cause for an intellect not to have actualised its cognitive potential. This is also spelled out by Suhrawardī in the following sentence. The point is that since the absence of a veil is negative, it can only be a condition for cognition, not its defining characteristic.

15 Šahrazūrī, Šarh Hikmat al-išrāq, ad II.2.8.153, 368.

16 Cf. Suhrawardī, Hikmat al-išrāq II.2.9.153, 143-144; and Rüdiger Arnzen, Platonische Ideen in der arabischen Philosophie: Texte und Materialien zur Begriffsgeschiche von șuwar aflātūniyya und muthul aflātūniyya (Berlin and Boston: de Gruyter, 2011), 131-146.

17 Cf. Suhrawardī, Hikmat al-išrā $q$ II.2.11.169, 160.
} 
after all, for once the hierarchical order of incorporeal lights, or Platonic Forms, is there, it seems to be very much like the universal blueprint of Avicenna's providential order. The crucial distinction is that in Suhrawardī's model, God's knowledge does not end at this level, but instead encompasses, through a series of mediations, all the consequences, down to the speck of dust of Qur'ān 34:3, of the downward causal agency of the hierarchy of lights. But this still leaves open the question of whether Suhrawardi's God knows the particulars, not in a universal way, as the Avicennian formula put it, but as the particulars they are. Note that contrary to the Avicennian theory, in which God's being an intellect entails that the objects of His knowledge must be universal, the more radical alternative is not obviously impossible in a relational theory of God's knowledge. If knowledge is nothing but a relation, it would seem to be inconsequential whether the other relatum is a universal order or a hierarchy in which the universal Forms encompass their particular instantiations. In either case, nothing would penetrate God's absolute unity.

Interestingly, God's knowledge of particulars as particulars is an idea Suhrawardī lays out already in the Talwịhăt and the Mašări ' wa-l-muțāraḥăt, where he compares the mediating role of the celestial intellects and souls to that of the cognitive organs of the body in human knowledge, rendering the celestial hierarchy an instrument for God's knowledge of the world! ${ }^{18}$ Just how far the analogy can be stretched is left somewhat vague, but a later chapter of the Mašăric wa-Imuțārahāt provides some further clarification. In discussing the knowledge of the celestial souls, on whose activity the particular events in the sublunary worlds of generation and corruption depend, Suhrawardi first rules out the possibility that the celestial souls know the particular effects of their activity in a temporal manner, that is, as the effects take place. ${ }^{19}$ Although the main objective of the argument is to explain the possibility of human knowledge of future contingent events, a phenomenon that would be incompatible with the celestial souls' temporal knowledge, 20 I believe it allows us to draw a similar moral concerning the question of God's knowledge. Hence, it does not seem likely that Suhrawardī held God to know particular temporal things temporally, or as they take place, for if that were the case, the celestial souls would have knowledge that God would lack, namely knowledge concerning future contingent things. But when it comes to knowing particulars as particulars, Suhrawardī makes the following tantalising remark in a later paragraph of the same chapter:

[The celestial souls have knowledge] only because [the things] that come to be have universal principles that must be reiterated, that is, that things recur in the likeness of what went before (ilā šabīhi mā kāna), not that what does not exist should return but that its like returns. Hence, they have, for instance, judgments concerning [things] that come to be, the whole of which takes place over each period of many millennia, regulated year after year and rotation after rotation, and then, once that period has elapsed, the motions come back to what is like the beginning. They have no regulation (maḍuttan) for how many reiterations these regulations entail in the world - for what is infinite is not regulated - but they boil down to a point (wa-in kāna wușūluhā

\footnotetext{
18 I have spelled out this discussion in Kaukua, 'Suhrawardī's Knowledge as Presence in Context'.

${ }^{19}$ Suhrawardī, Al-Mašāric wa-l-muțārahāt III.7.2.213, 491-492.

20 This is because if the celestial souls knew contingent things only when they take place, they would not have the knowledge that they are supposed to transmit to human souls.
} 
ilä l-nuqta), and perceiving what they entail is like adding conditional universals to them (istịnāa kullìyātin šarțiyatin 'indahā). ${ }^{21}$

One thing seems clear in this dense passage: the celestial souls know the universal principles of particular things. These principles, however, are universal in a rather special sense. Since the celestial souls' atemporal knowledge of particulars must be finite, lest it constitute an actually infinite ordered series, Suhrawardī here endorses a cyclical view of history, according to which all events recur eternally in exactly the same succession. ${ }^{22}$ Hence, instead of essences common to particulars that can be both synchronically and diachronically many (like the essence of horse to many horses), the principles in the celestial souls' knowledge are principles for particulars that are synchronically singular, and only diachronically many (like the essence of Bucephalus for the Bucephaluses in each cycle of history). The souls know the whole of all such principles in an atemporal, point-like cognitive act. But although this act is unextended, or non-discursive, it does have an internal structure, which Suhrawardī says is "like adding conditional universals". It is not entirely clear how this should be understood, but one possibility is that the celestial souls' judgments concerning things that come to be in time should be conceived as "additive" (istitnāî) syllogisms. Suhrawardī's examples of such syllogisms are modus ponens and modus tollens, ${ }^{23}$ where the first premise ('if $x$, then $y^{\prime}$ ) is conditional (šartil) and the second premise adds or repeats (istatna'a) either the antecedent or the (negation of the) consequent. Hence, the judgments of the celestial souls would have a hierarchical structure, where the more general principles are conceived as sets of conditional sentences, and their specifications add one of the antecedents, yielding the principle of the particular thing as the consequence.

Be that as it may, one clear outcome of this passage is that the celestial souls, and a fortiori God, do know particulars "in a universal way", after all.24 That Suhrawardī himself endorsed this view is suggested by his closing remark: "The argument would be ours, were it not that the doctrine belongs to the ancients among the Babylonians, the Hosrawāni sages, and the Hindus, as well as all of the most ancient [peoples] from Egypt, Greece and elsewhere."25 If there is a difference between the Avicennian view and that of Suhrawardī, it seems to boil down to the fact that Suhrawardi states more explicitly that the atemporal knowledge of particulars through their principles amounts to knowing the complete descriptions of those particulars, down to the most fleeting accidents. On the other hand, it is possible that Suhrawardī interpreted Avicenna, possibly correctly, as saying that God's knowledge is strictly limited to the general blueprint of the providential order that we have seen him deny.

The reason why this is a pressing concern is that the Peripatetic theory of providence was a particularly potent way of answering the problem of evil: the undeserved suffering of particular creatures is not part of God's providential plan, because that only concerns the best possible ordering of the world at a general level. God does not want any particular to suffer, of course, but this is simply because He is not concerned with particular creatures in the first place, and has His

\footnotetext{
21 Suhrawardī, Al-Mašāric wa-l-muțārahāt III.7.2.213, 492-493.

${ }^{22}$ In this regard, Suhrawardī differs from Avicenna who expressly argues against eternal recurrence; see Rashed, 'Théodicée et approximation: Avicenne'.

${ }^{23}$ Suhrawardī, Talwịhăt I.5.1.1, 51 (Habībī); for the background, see Kwame Gyekye, 'The Term istithnā’ in Arabic Logic', Journal of the American Oriental Society92/1 (1972): 88-92.

${ }^{24}$ Indeed, this would not be very far from the interpretation of Avicenna's theory of God's knowledge put forth in Peter Adamson, 'On Knowledge of Particulars', Proceedings of the Aristotelian Society 105/3 (2005): 257-278.

${ }^{25}$ Suhrawardī, Al-Mašāri' wa-l-muțārahāàt III.7.2.214, 493.
} 
regard exclusively directed to the universal order that they instantiate. Indeed, perhaps God cannot know suffering even in universal terms, for suffering is a form of privation of the actuality specific to a certain essence, and it is highly questionable whether privations are knowable by incorporeal subjects. ${ }^{26}$ If the foregoing account is on the right track and Suhrawardi's works are witness to a consistent attempt at broadening the compass of God's knowledge to cover particular creatures, it is natural to ask whether he can still endorse the Avicennian theodicy. If God knows the particulars, whether as particulars or through their complete descriptions, how can he allow so many entities to be deprived of their specific blossoming?

Despite his departure from Avicenna in the question of providence, Suhrawardī endorses his predecessor's conviction according to which the actual world is the best possible, and he does this on the Avicennian grounds that were it possible to create a world in any respect better than the actual one, God would be withholding that possibility of a greater good from His creatures, which would compromise His benevolence. But as any parodist of classical theodicy can easily show us, possible worlds, in which this or that particular evil is left unrealised, are readily conceivable. The poor kid that gets run over by a truck could have survived, had he left his home five seconds later or earlier - what is contradictory about that? Moreover, laymen constantly beseech God or His angels to intervene in such cases, and there is widespread belief among them that such interventions in fact do take place, perhaps much more often than we care to admit.

Suhrawardī engages with the problem of evil at the greatest length in the Mašāric wa-Imuțārahăt, where he begins by arguing why generation and corruption, and thus death and decay, are necessary in the best possible world. The underlying principle is God's infinite generosity, the monotheistic version of the ancient principle of plenitude. If God is infinitely generous, then surely it is more appropriate for Him to give existence to a greater rather than a lesser number of beings. But for any finite number, we can always think of a greater number, and as a consequence, an infinitely generous God must give existence to an infinite number of beings - and in particular, an infinite number of rational human souls, the crème de la crème of generated entities. Yet the universe is demonstrably finite in its spatial extension, and as a consequence it can house only a finite number of beings at each moment of time. The way out of this dilemma is provided by the infinite temporal succession of generated and corruptible beings. This requires matter as well as a certain amount of opposition between the elemental constituents of concrete entities:

Were it not for opposition, generation and corruption would not be possible, and were it not for generation and corruption, the existence of infinite individuals would not be possible. Elemental species can only occur through interaction ( $\operatorname{tafā}^{-} u()$, and some opposition is necessary for interaction. Hence, it is valid that were it not for opposition, the permanent and constantly renewed emanation would not be possible, no infinite amount of rational souls would occur, the elemental world would be

${ }^{26}$ Indeed, Avicenna says that the human capacity to know potentialities and privations is due to our embodiment (Šifä': Nafs V.5, 238). 
prevented from life, and most of what is possible would remain in pure nonexistence. ${ }^{27}$

But due to the opposition between different elemental constituents that they entail, generation and corruption necessarily give rise to conflicting tendencies in material existence. One thing's generation is the corruption of another, and corruption is plausibly conceived as a kind of suffering, and therefore an evil, from the point of view of the individual entity subject to it. Suhrawardi does not shy away from this inference; as a matter of fact, he openly endorses the idea that some amount of evil is a necessary consequence of the principle of plenitude. Since he subscribes to Avicenna's definition of evil as privation of existence, or privation of the perfection of existence, of something, evil is bound to take place in a universe of conflicting tendencies. But it is only when these individual cases are considered in the bigger picture of the harmonious order of things that they are put into the proper perspective:

When that which brings evil into being with regard to an individual is considered from the perspective of the universal order (al-nizām), it is good insofar as existence cannot encompass any more of the good and the order than [it does] through it.28

Here in the sublunary world, the teleological trajectories of individual things may clash, and one thing may harm another while pursuing its own specific end. Given the essential nature of fire to burn, it is inevitable that it will occasionally burn down something valuable, the loss of which causes undeserved suffering, such as the cloak of a virtuous ascetic. ${ }^{29}$ But it is much more common, so the argument goes, that fire works to benefit human beings by keeping us warm, helping us cook our food and rid it of potentially lethal impurities, and so forth. If we compare the rare cases of suffering caused by fire-related accidents, we find them to be statistically insignificant, indeed incomparable, in relation to the benefits (mașallih, sing. mașlaha) that fire constantly brings to the vast majority of the species. ${ }^{30}$ It would be a greater evil for God to forsake such a great good for the sake of a minor evil; in other words, if one considers the harmonious order of the world, there simply is no evil.

All of this is familiar from Avicenna, of course, which raises the question of whether Suhrawardī is merely reporting a view that, like the theory of providence, he ultimately rejects. However, unlike providence, the theodicy intimately related to it seems to represent Suhrawardī's considered position, for the Hikmat al-išrāq adds little of substance to this account. ${ }^{31}$ A further signal of allegiance to Avicenna's view is Suhrawardì's spitefully critical discussion of a contemporary attempt at clearing room for God's intervention in the causal chains of the world of generation and corruption. The majority of the material he attacks is derived from

\footnotetext{
27 Suhrawardī, Al-Mašāric wa-l-muțārahāātIII.6.11.195, 466-467.

28 Suhrawardī, Al-Mašāric wa-l-muțārahāt III.6.11.195, 467.

${ }^{29}$ Suhrawardī, Al-Mašăric wa-l-muțāraḥātIII.6.11.200, 472-473.

30 The use of the jurisprudential term mașlaha in this context is noteworthy. In classical Islamic jurisprudence and political theology, maslaha denotes the common good of the Muslim community, and as such it is conceived as the underlying principle, the abstract ratio legis of šarīa. The metaphysical use of the term fits with the jurisprudential sense of common good, but only if the relevant community is conceived of as the entire cosmos. Suhrawardĩ explicitly rules out the benefits of individual human beings, and even of the entire species, from the point of view of the harmonious order of the world. Cf. Suhrawardī, al-Mašăric wa-l-muțārahăt III.6.11.196, 467-468, discussed below.

31 The relevant section is Suhrawardī, Hikmat al-išrā $q$ II.5.4.249-250, 235-236.
} 
Abū l-Barakāt al-Baġdādī (d. 559/1165), a highly contentious interpreter and critic of Avicenna, to whom Suhrawardī denigratingly refers as the "insane practitioner of medicine" who merely "emulates the wise",32 and whom he accuses of needlessly prolonging the discussion of providence and the problem of evil.

Turning briefly to Abū l-Barakāt's Kitāb al-mu'tabar fíl-hikma, we find that he does indeed take his time with a careful interpretation of the Qur'ānic concepts of qaḍā'and qadar, or God's decree and power. ${ }^{33} \mathrm{He}$ defines qad $\bar{a}$ ' as the universal order (al-amr) that is either foreknown by God or entailed by the joint movement of the celestial spheres as a whole, while qadar is the execution of that order in a descending causal chain down to the minutest details of the sublunary world. ${ }^{34}$ Thus, although Abū l-Barakāt sticks to the theological vocabulary throughout his discussion, we are firmly placed on the conceptual terrain of Suhrawardī's debate concerning providence. He then distinguishes three different theories of qadăand qadar by means of their respective answers to two questions: (i) whether God foreknows particular things or only the universal order that is executed by the motion of the celestial spheres, and (ii) whether human acts are causally determined like all other things and events in the universe. True to the guiding principle of his book, which is to review all the available theoretical data on a given question in order to finally arrive at a considered view, ${ }^{35} \mathrm{Abu}$ 'l-Barakāt thus brings to the table schematic versions of not only the theory of the philosophers (2), but also two other theories, which resemble the doctrines of the rival theological schools of the Ash'arites (1) and the Mu'tazila (3). The three theories are:

(1) God foreknows both universal and particular things, and all events, including human acts, are determined by Him;

(2) God does not foreknow particular things but only the universal order of the world; all events, including human acts, are determined by Him, albeit not immediately but through the mediation of the celestial intellects, souls and spheres;

(3) God does not foreknow particular things but only the universal order of the world; all other events are determined by Him (through the mediation of the celestial intellects, souls and spheres), but human acts are undetermined. ${ }^{36}$

Abū l-Barakāt himself does not straightforwardly commit to any of the views. He reviews the motivations behind them, sympathising with both the Ash'arite endorsement of God's omniscience and omnipotence and the Mu'tazilite commitment to God's justice. The conflict between these concerns is, of course, familiar from textbooks of theology. If God's omnipotence

\footnotetext{
32 Suhrawardī, Al-Mašāric wa-I-muțārahāt III.6.11.197, 471, and III.6.11.196, 468, respectively.

33 See, for instance, Q 2:117, 3:47, 19:35, and 40:68 for qadā'; and 16:70 and 42:50 for qadar.

${ }^{34}$ Abū l-Barakāt, Al-Kitāb al-Mu'tabar fị l-ḥikma, no ed., 3 vols. (Hyderabad: Da’ira al-ma'ārif al-'Uthmāniyya, 13571358 H), III.2.8, III.180-181.

35 On this methodological principle, see Shlomo Pines, 'Nouvelles études sur Awḥad al-Zamân Abu'l-Barakât alBaghdâdî', in S. Pines, Studies in Abu'l-Barakāt al-Baghdādī: Physics and Metaphysics (Jerusalem \& Leiden: The Magnes Press \& E. J. Brill, 1979), 96-173.

${ }^{36}$ Abū l-Barakāt, Mu'tabarIII.2.8, III.181-182. Note that Abū l-Barakāt does not identify the theories. They remain very schematic characterisations, albeit ones that exhaust the theoretical alternatives (see III.2.9,192-193), and it is difficult to determine whether the author even had particular representatives in mind. Indeed, they may be conscious abstractions on the basis of real theories that Abū l-Barakāt knew (for instance, in III.2.9, 193, Empedocles' theory of love and strife is briefly mentioned, only to be reduced to the first alternative). The ascription of the third theory to the Mu'tazila is particularly problematic due to its distinctly Avicennian aspects, like the denial of God's knowledge of particulars.
} 
and omniscience are conceived absolutely, they must include human acts. But then God knows what we are about to do before we do it, indeed in the final analysis He is the real agent of our acts, and if responsibility for an act is a precondition of moral desert, this raises the question of whether God's rewarding or punishing us for His acts can be just. Yet if we are free to choose whether to perform virtuous or vicious acts, God's omnipotence and omniscience are compromised; our free acts are by definition both beyond His power and unknowable prior to our decisions to act in a certain way.

Committed to both God's omnipotence and justice, Abū l-Barakāt attempts to break a new, intermediate path - with debatable success. ${ }^{37}$ He endorses the Ash'arite idea of God's omnipotence but excludes from God's knowledge the infinite possibilities that are never actualised, thus confining it to what God in fact does choose to create. This is because he subscribes to the general principle that all knowledge must be finite, thinking that because the requirement is due to the nature of knowledge, finitude does not entail any incapacity in God. ${ }^{38} \mathrm{~A}$ further departure from the Ash'arite view is that the things God knows are identified with the universal essences or natures that constitute the metaphysical order of the world. Abū l-Barakāt seems to come very close to Avicenna's principle of God knowing particulars in a universal way when he adds that in addition to the universal principles, God also knows their particular instantiations in the sense that they proceed in an unchanging fashion from the principles. But betraying his Mu'tazilite sympathies, Abū l-Barakāt deviates from the philosophers and the Ash'arites alike in his repeated insistence that subjecting human freedom to God's foreknowledge and omnipotence, like the Ash'arites do, or to a deterministic unfolding of the fixed order of the world in the manner of the philosophers' theory, undermines any consistent religious morality, and violates our common sense beliefs concerning human agency. ${ }^{39}$ Although Abū l-Barakāt does recognise that human agency may not be entirely unaffected by extrinsic causes, he claims that considerations of God's justice force us to commit to the freedom and indeterminacy of human acts, which makes them unavailable to divine foreknowledge, even in the universal way. ${ }^{40}$

Human agency thus introduces a fundamental indeterminacy to the world. Of course, adding an extrinsic causal principle to the series of natural causes will result in further indeterminacy as we proceed down the line of consequences. Hence, Abū l-Barakāt is lead to exclude another class of events from divine foreknowledge, namely those events that are due to both natural and voluntary causes, a class he refers to as chance (ittifāqì) events and characterises by means of an interesting example. ${ }^{41}$ Suppose that Zayd and a scorpion are making their way along intersecting paths. If both travel at a certain pace, they will encounter each other, in which case either Zayd will trample the scorpion or the scorpion will sting Zayd, but if either of them deviates from that pace, the encounter will fail to take place and both will travel along intact. Such a scenario involves factors that are predictable by knowledge of the respective natures of Zayd and the scorpion; for example, the scorpion will inevitably sting Zayd due to its natural inclination, given the right circumstances. But there are also factors that are unpredictable, a case in point being Zayd's decision to quicken his pace. ${ }^{42}$ Because of these factors, it is a matter of

\footnotetext{
${ }^{37}$ For an in-depth discussion of Abū l-Barakāt's theory of action, see Mariam Shehata, 'Abū l-Barakāt al-Baghdādī on Divine Foreknowledge and Human Free Will', Nazariyat6/2 (2020): 99-131.

38 Abū l-Barakāt, Mu'tabar III.2.9, III.187.

39 Abū l-Barakāt, Mu'tabar III.2.9, III.192-195.

40 Abū l-Barakāt, Mu'tabar III.2.9, III.191-192.

${ }^{41}$ Similar examples are known from ancient texts, the locus classicus being Ar. Phys. II.4, 196a1-15. See Richard Sorabji, Necessity, Cause, and Blame: Perspectives on Aristotle's Theory (Ithaca: Cornell University Press, 1980), 3-25.

42 Abū l-Barakāt, Mu'tabar III.2.9, III.188-189.
} 
chance or luck whether Zayd will meet with the scorpion, and as a consequence, not even God will be able to tell whether the meeting takes place before it actually does or does not. And extending the thought experiment one step further, we see that the subsequent causal history of the world is irredeemably affected by the chance incident, for it determines whether a certain causal agent (Zayd or the scorpion) continues to exist or not.

Voluntary and chance events thus ruled out of God's foreknowledge, Abū l-Barakāt turns back to the concern over His justice, which he attempts to reconcile with creaturely freedom by conceiving of God's knowledge and will as temporal events:

As regards God most high not having a temporally occurring will concerning and due to [things] that come to be in time (irādatun ḥāditatun fi l-ḥawāditi wa-bi-ḥasabihā), we have already falsified and refuted this doctrine in refuting him who denies God's knowledge of particulars. On the contrary, He most high hears, sees, rewards, punishes, and is angered and satisfied, attending and turning as He wants to what $\mathrm{He}$ wants. He is not determined (lä tatahakkamu 'alayhi) by any causes, for it is rather He that judges them and according to them, and what is necessitated by Him changes and is renewed as required by [His] wisdom, [and He necessitates things] in accordance with the pleas and exigencies (al-dawāî́ wa-l-sawāriff) that He knows and inspects in the entire world, in which there is no veil veiling His knowledge and inspection, and nothing to prevent Him. ${ }^{43}$

Hence, God knows what his individual creatures do, but only after the fact. What is even more striking, He intervenes in the world on the basis of His knowledge, in order to reward and punish His people, as well as to meet their pleas. This, however, entails no passivity in God:

In terms of causes, His [temporally] occurring volitions and [the things] that He wills are traced back to two causes, an efficient one and what is required (muqtadin). The efficient cause is in His complete wisdom, which sets each thing in its proper place in terms of acting and being acted upon and in terms of what follows and what is followed. What is required is what He knows at every moment of renewed generated states, in accordance with which He acts, and so He is as the Greek sage has said. He reviews the requests of those pleading verbally in terms of whether they deserve what they ask for. He hears and sees or acts by His wisdom according to what He knows of what He has seen and heard. ${ }^{4}$

Fully aware of the looming problem of reactivity or passivity in God, Abū l-Barakāt introduces a distinction between two causal factors in God's interventions. God's wisdom with its intrinsic goodness is the one and unchanging efficient cause, but because it has to be manifested in different ways in order to meet the needs and deserts of His subjects, it must be conditioned by knowledge of the circumstances of His act. In a strict sense, God does not react, but "reviews" the

43 Abū l-Barakāt, Mu'tabar III.2.9, III.191.

${ }^{44}$ Abū l-Barakāt, Mu'tabar III.2.9, III.191. 
situation and acts according to what He thereby sees and hears in a manner that best matches with the principles of His uniform wisdom.

Motivated by theological and ethical concerns, Abū l-Barakāt thus arrives at a theory that is rather close to the Mu'tazila. The one premise he is unwilling to compromise is God's justice, and in order to make room for it, he is prepared to accept the problematic ideas of God's temporal knowledge and of voluntarily introduced breaks in the causal closure of the world. It is precisely this order of preference that Suhrawardī attacks when he accuses Abū l-Barakāt of committing to the unfounded anthropocentric assumption "that the world was only created for the sake of man". ${ }^{45}$ He does not hide his contrary commitment to the determinist foundations of philosophy, and states that if we open the door to the kind of will-induced indeterminacy Abū l-Barakāt endorses, "there will be no universal and principled norms here" anymore.46 But most importantly, instead of solving the problem of evil, Abū l-Barakāt's idea of divine intervention exacerbates it:

The Giver of the Decree (al-qädir) - whose acts of will the laymen and the practitioner of medicine, who emulates the wise, estimate to occur anew for the sake of interests (mașāliḥ) - did not destine (mā aqdara) that man is not blinded and his temperament is preserved, that widows are not neglected, that guardians of privacy are not regularly violated (lā yuhtaka bi-l-faqri katîrun min arbābi l-satr), that young orphans are not left unnursed and unfostered, which would afflict both the orphans and [their nurses], that manifold diseases are not sent down, and that false religions with their dogmas, captives, and plundering do not gain power. If the acts of will of He who decrees that [something] not be done occurred anew - as he said, "He chooses it and [it] is, and if [something] is, He has chosen it" - why has He not willed the best interest (mașlaha) of this individual? Since acts of will are like that, Zayd's blindness or the length of 'Amr's life are not important for universal order (al-nizām). 47

Suhrawardī's counterargument thus appeals to a commonsensical intuition concerning God's justice. If God not only knows particulars but can also intervene in mundane causal chains in the interest of those particulars, why does He not do this in every case? Why is Zayd blind but Huâlid endowed with excellent vision? Why did 'Amr's life end prematurely, if this could have been prevented? And even if the possible benefits respective to two persons were mutually exclusive, on what basis does God choose in whose interest He acts? Although the philosophers' answer, according to which God determines the universal harmony of the world but does not interfere with its unfolding, may not satisfy commonplace emotional reactions to creatural suffering, in face of the subsequent questions it clearly emerges better equipped to meet the problem of evil.

Suhrawardī is equally determined to defend philosophy against the Ash'arite claim that we should not inquire into God's reasons in such subsequent questions. ${ }^{48}$ The Ash'arites' bi-lākayfa ruins all theoretical discussion, for "if the door of 'there is no asking why' is opened

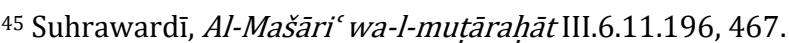

46 Suhrawardī, Al-Mašāric wa-l-muțārahāt III.6.11.196, 467.

47 Suhrawardī, Al-Mašāric wa-l-muțārahāt III.6.11.196, 468.

48 This is no longer an argument Abū l-Barakāt would have been likely to endorse, for as we have seen, he leans towards the philosophers and the Mu'tazila in founding God's activity on wisdom, the principles of which are understandable to us.
} 
concerning [things] of understanding, then whenever one intends to argue [for something] [...], the opponent will say, 'there is no asking why'." 49 This will turn against the Ash'arites' own proof for God's existence from the contingent world's need of necessitation, or their arguments for the positive existence of God's attributes.

To conclude his discussion, and to signal once more his wholesale endorsement of Avicenna's solution to the problem of evil, Suhrawardī answers Abū l-Barakāt's worry concerning the justification in God's meting out of rewards and punishments. To recall, if God does not know the particular agents and their acts, how can He punish or reward them in a non-arbitrary way? Here is Suhrawardì's answer:

Know that happiness [takes place] more often than misery, the classes (marätib) of people in the hereafter are like their classes in this world, and happiness and misery come in degrees (marātib). Once the foregoing is known, there is no way for anyone to say: 'If all is due to destiny (bi-l-qadar), why is there punishment?' For vile character traits and excessive features (al-hay'āt) necessitate pain by themselves, not due to an extrinsic avenging force (satwa). When a patient falls short of [his] diet and hardships overcome him, this is not due to the prognostic physician avenging him, rather it is concomitant to what destiny conveys to him from gluttony. 50

In other words, no additional reward is needed for virtue, nor does punishment have to be meted out for vice, because the states of the virtuous and vicious souls are rewarding or punishing as such. Hence, there is no need to revise the general answer to the problem of evil. This of course gives rise to a number of further questions, such as whether Suhrawardī held a view like that of Stoic ethics, according to which it is more fortunate to live under extreme duress but excel in virtue than to enjoy tranquil external conditions but lapse into vice. More critically, one could say that his answer still leaves unanswered the second-order question of the desert of the virtuous or vicious character as such, given that in a deterministic framework, neither can be acquired in any robust sense of the word. With regard to the latter point, however, Suhrawardi does seem to have an answer, albeit one that again violates the ethical intuitions behind the question: although it might indeed seem unfortunate that some souls end up corrupt, statistically speaking there is more virtue and reward than vice and punishment - and this much should satisfy any rational person.

To conclude, it is clear that Suhrawardī does not link his denial of providence to any robust notion of either divine or human will. God creates due to His essence and knows the creation through its manifestation to Him, but never intervenes in its unfolding. By the same token, although human agency is the result of a combination of extrinsic andintrinsic causes, there is no sign that the latter include any principle of radical freedom. The evidence we have looked at

${ }^{49}$ Suhrawardī, Al-Mašāric wa-I-muțārahāt III.6.11.196, 469.

${ }^{50}$ Suhrawardī, Al-Mašāric wa-l-muțāraḥāt III.6.11.200, 473; cf. Avicenna, Ishārāt (in Ibn Sīnā, Le livre des théorèmes et des avertissements, ed. by J. Forget (Leiden: E. J. Brill, 1892)), namaț 7, 189-190. 
suggests that Suhrawardī's final view is based on a careful weighing of the pros and cons of the alternatives. Endorsement of Avicenna's theory of creation allowed him a solution to the problem of evil, or at least a way of explaining why our commonplace moral intuitions do not constitute a genuine philosophical problem. The price to pay, of course, is a strong determinism, but judging by Suhrawardì's refutation of theological voluntarism by means of its scandalous consequences, it seems that if he considered determinism a sacrifice in the first place, it was definitely smaller than the exacerbation of the problem of evil through the voluntarist alternative.

This brief investigation allows us to reconsider the controversial relation between Suhrawardī's works. As I hope has become clear, there is a sense in which the Talwịhāt and the Mašăric wa-l-muțāraḥāt are "Peripatetic" works. By no means representing a distinct phase in Suhrawardī's brief career, they do pave way for the more radical departure of the Hikmat al-išrāq by engaging at considerable length, certainly much greater than the epitomic first part of the Hikmat al-išrāq, with the critical exposition of the views that the latter work was intended to replace. In this sense the two works seem very sympathetic to Avicenna, indeed prepared to develop his views in ways that Suhrawardī considered their most charitable interpretation. A particularly striking case in point is the theory of presential knowledge, frequently seen as a quintessentially išrāäìidea, which Suhrawardī presents in all his works as an attempt to deal with the question of God's knowledge in an Avicennian framework. It is an open question whether the idea is reconcilable with Avicenna, but it is most definitely not straightforwardly derivable from his works.

At the same time, it is not always easy to see where exactly Suhrawardi departs from the Peripatetic model and where he tacitly endorses it. The question of providence, or of God's knowledge more generally, is a good example of this. Despite Suhrawardi's vehement criticism of the idea of providence, he seems to have had no qualms about Avicenna's intimately related solution to the problem of evil. Indeed, his reaction to the strong voluntarism of the Ash'arites and Abū l-Barakāt signals a firm commitment to the Peripatetic's rationalist theory of creation. ${ }^{51}$

\section{Bibliography}

\section{Primary literature}

Abū'l-Barakāt, $M u^{\prime}$ tabar = Abū'l-Barakāt al-Baġdādī, Al-Kitāb al-Mu'tabar fi-l-hikma li-sayyid alḥukamā’ A wḥad al-Zamān Abì'l-Barakāt Hiba Allāh ibn 'Alī ibn Malkā al-Baghdādī. No ed. 3 vols. Hyderabad: Dā’irat al-ma‘ārif al-'Uthmānīya, 1357-1358/1937-1938.

Avicenna, Ishārät = Avicenna. Le livre des théorèmes et des avertissements. Ed. by J. Forget. Leiden: E. J. Brill, 1892.

Avicenna, Shifä̀: Ilāhiyyāt = Avicenna. The Metaphysics of The Healing. Al-Shifä': al-Ilāhìyāt. A Parallel English-Arabic Text. Ed./tr. by Michael E. Marmura. Provo: Brigham Young University Press, 2005.

Avicenna, Shifä': Nafs = Avicenna's De anima (Arabic Text). Being the Psychological Part of Kitāb al-shifä. Ed. Fazlur Rahman. London: Oxford University Press, 1959.

\footnotetext{
51 I would like to thank the audiences in Palermo and Paris for their comments on an early version of this paper, as well as the anonymous referee for perspicacious suggestions. The research was supported by the Academy of Finland and the European Research Council (grant agreement no. 682779).
} 
Šahrazūrī, Šams al-Dīn. Šarh Hikmat al-išrāq = Commentary on the Philosophy of Illumination by Shams al-Din Muhammad Shahrazuri. Ed. by Ḥusayn Żiā’ī Turbatī. Tehran: Institute for Humanities and Cultural Studies, 2001.

Suhrawardī, Hikmat al-išrāq $=1-260$ in Suhrawardī. OEuvres philosophiques et mystiques (Shihābuddīn Yahyā Suhrawardī). Tome II: 1. Le Livre de la Théosophie Orientale, 2. Le Symbole de foi des Philosophes, 3. Le Récit de l'Exil Occidental. Textes édités avec prolégomènes en français. Ed. Henry Corbin. rpt. Tehran: Institute d'Études et des Recherches Culturelles, 2009.

Suhrawardī, al-Mašārí wa-l-muțārahăàt = 193-506 in Suhrawardī. OEuvres philosophiques et mystiques (Shihābuddīn Yahyā Suhrawardī). Tome I: La Métaphysique: 1. Kitāb alTalwīhāāt, 2. Kitāb al-muqāwamāt, 3. Kitāb al-Mašāri` wa-l-muțārahăāt. Ed. by Henry Corbin. Rpt. Tehran: Institute d'Études et des Recherches Culturelles, 2009.

Suhrawardī, Talwịhāt Corbin = 1-121 in Suhrawardī. OEuvres philosophiques et mystiques (Shihābuddīn Yahyā Suhrawardī). Tome I: La Métaphysique: 1. Kitāb al-Talwīhāât, 2. Kitāb al-muqāwamāt, 3. Kitāb al-Mašăric wa-l-muțārahăt. Ed. Henry Corbin. Rpt. Tehran: Institute d'Études et des Recherches Culturelles, 2009.

Suhrawardī, Talwịhāt Ḥabībī = Suhrawardī. Al-Talwịhāt al-lawḥīyah wa-l-'aršìnah. Ed. by Nağafqulī Ḥabībì. Tehran: Iranian Institute of Philosophy, 2009.

\section{Secondary literature}

Adamson, Peter. 'On Knowledge of Particulars'. Proceedings of the Aristotelian Society 105/3 (2005): 257-278.

Arnzen, Rudiger. Platonische Ideen in der arabischen Philosophie: Texte und Materialien zur Begriffsgeschiche von șuwar aflātūniyya und muthul aflātūniyya. Berlin and Boston: de Gruyter, 2011.

Belo, Catarina. Chance and Determinism in Avicenna and Averroes. Islamic Philosophy, Theology, and Science Texts and Studies 69. Leiden and Boston: Brill, 2007.

Da Silva, Mateus Domingues. "La métaphysique des lumières de Suhrawardī et la question de la connaissance divine', Mélanges de I'Institut dominicain d'études orientales 34 (2019): 147-197.

Dubé, Jonathan. 'Hayy ibn Yaqzān's of the Two Generous Men in Avicenna's Decree and Determination ( $R$. fi I-Qaḍā’ wa-I-qadar)'. Intellectual History of the Islamicate World 7 (2019): 35-60.

Gyekye, Kwame. 'The Term istithnā’ in Arabic Logic'. Journal of the American Oriental Society 92/1 (1972): 88-92.

Janssens, Jules. 'What about Providence in the Best of All Possible Worlds? Avicenna and Leibniz'. In Fate, Providence and Moral Responsibility in Ancient, Medieval and Early Modern Thought: Studies in Honor of Carlos Steel. Ed. by Pieter d'Hoine \& Gerd van Riel. Leuven: Leuven University Press, 2014, 441-454.

Kaukua, Jari. 'Suhrawardī's Knowledge as Presence in Context'. Studia orientalia 114 (2013): 309-324. 
Kaukua, Jari. Self-Awareness in Islamic Philosophy: Avicenna and Beyond. Cambridge: Cambridge University Press, 2015.

Lizzini, Olga L. 'Matter and Nature: On the Foundations of Avicenna's Theory of Providence: an Overview'. Intellectual History of the Islamicate World 7 (2019): 7-34.

Nusseibeh, Sari. 'Avicenna: Providence and God's Knowledge of Particulars'. In Avicenna and His Legacy: A Golden Age of Science and Philosophy. Ed. by Y. Tzvi Langermann. Turnhout: Brepols, 2009, 275-288.

Pines, Shlomo. 'Nouvelles études sur Awḥad al-Zamân Abu'l-Barakât al-Baghdâdî'. In Shlomo Pines. Studies in Abu'l-Barakāt al-Baghdādĩ: Physics and Metaphysics. Jerusalem \& Leiden: The Magnes Press \& E. J. Brill, 1979, 96-173.

Rashed, Marwan. 'Théodicée et approximation: Avicenne'. Arabic Sciences and Philosophy 10/2 (2000): 223-257.

Shehata, Mariam. 'Abū l-Barakāt al-Baghdādī on Divine Foreknowledge and Human Free Will'. Nazariyat 6/2 (2020): 99-131.

Shihadeh, Ayman. 'Avicenna's Theodicy and al-Rāzī's Anti-Theodicy'. Intellectual History of the Islamicate World 7 (2019): 61-84.

Sorabji, Richard. Necessity, Cause, and Blame: Perspectives on Aristotle's Theory. Ithaca: Cornell University Press, 1980.

Steel, Carlos. 'Avicenna and Thomas Aquinas on Evil'. In Avicenna and His Heritage: Acts of the International Colloquium, Leuven-Louvain-la-Neuve September 8-September 11, 1999. Ed. by Jules Janssens \& Daniel de Smet. Leuven: Leuven University Press, 2002, 171-196.

Walbridge, John. 'Suhrawardīs (d. 1191) Intimations of the Tablet and the Throne: The Relationship of Illuminationism and the Peripatetic Philosophy'. In The Oxford Handbook of Islamic Philosophy. Ed. by Khaled El-Rouayheb \& Sabine Schmidtke. New York: Oxford University Press, 2017, 255-277. 